\title{
Pulled two ways: Norms of 'Pacificness' and journalism in New Zealand's Pacific news media
}

\section{Tara Ross}

Department of Media and Communication, University of Canterbury, Christchurch, New

\section{Zealand}

tara.ross@canterbury.ac.nz

Dr Tara Ross is a senior lecturer and head of the journalism programme at the University of

Canterbury, where she is also a research fellow with the Macmillan Brown Centre for Pacific Studies.

She was an award-winning senior reporter for The Press and the Sunday Star-Times newspapers, and has worked as both a freelance writer and editor, as well as for community news publications. She is of Pākehā and Tuvaluan descent, and studies journalism, diversity issues, ethnic minorities and Pacific media.@taraross_nz,orcid.org/0000-0002-6664-711X 


\section{Pulled two ways: Norms of 'Pacificness' and journalism in New Zealand's Pacific news media}

By looking at how Pacific media producers position themselves in different contexts, this paper identifies complex identity politics within the communities of practice of New Zealand's Pacific news media production. Interviews with 23 Pacific news media producers reveal a tension between two fields of journalistic and Pacific norms that hinge upon different locative practices - strategic ploys to locate oneself and one's media in relation to community and to other Pacific and mainstream media and appear to depend on each media outlets' positioning in relation to language, mainstream institutions and their ethnic community. Analysis of these locative practices helps to reveal some of the power relations embedded in Pacific media outlets' structural, cultural and ideological contexts. Unlike members of the dominant group, who have arguably more stability in identity, Pacific peoples' identity is always negotiated, and in ways that must continually answer back to the different forces that position them.

Keywords: Journalism, Identity, Pacific media, locative practice

This paper explores how Pacific news media producers position themselves in Aotearoa New Zealand, and suggests that by looking at the locative nature of their practices we might fine-tune the ways we theorise ethnic media and their role in constructing identity and community. By examining how Pacific producers account for themselves in different contexts, this study identifies complex identity politics within the communities of practice of media production. In producers' strategic use of discourses of 'Pacificness', in particular, it finds differences in the meaning-making of Pacific producers, who are differentiated by being 'Pacific-leaning' or 'journalism-leaning', that is, pulled in different ways by a domain of 
Pacific norms and practices and a domain of journalism norms and practices that ask different things of them.

Indeed, to understand Pacific news media, this paper argues that we need to view the Pacific media space as a space of tension. Pacific media straddle both Pacific and journalism fields, which often require and prioritise different things, and all sorts of production challenges and a wide range of responses to those challenges emerge as a result. Against these differences, however, this paper suggests that these media are united in their need to position themselves as 'Pacific' - in relation to their Pacific communities, each other, and mainstream media and dominant institutions. While the Pacific media studied here performed that locative need in different ways, and with recourse to different resources, they all performed it. In other words, the practice of locating oneself and one's media in terms of identity, community and tūrangawaewae (place to stand) appears to be characteristic of the Pacific media in this study.

By exploring the differences in Pacific media producers' practices and discourse (mainly in relation to categorisations of 'Pacificness') this paper attempts an explanation for some of the apparent tensions within Pacific media based on ideas of locative practice and identity negotiation. It also demonstrates the diversity of Pacific media and the need to develop theories that can account for multiplicity and conflict within an ethnic mediascape.

\section{Pacific peoples and media in New Zealand}

New Zealand's Pacific communities comprise multiple and diverse ethnic groupings as well as distinct generational communities of island-born and New Zealand-born (with the latter increasingly using English rather than a Pacific language). As a group, they comprise 
the fourth-largest major ethnic group in New Zealand, behind Pākehā (New Zealand European), Indigenous Māori and Asian ethnic groups, which is marked by linguistic and cultural diversity, geographic spread throughout the country and a significant intergenerational divide.

The Pacific population is made up primarily of Samoan, Cook Islands, Tongan, Niuean, Fijian and Tokelauan groups, with smaller numbers from Tuvalu, Kiribati, Papua New Guinea, Vanuatu, the Solomon Islands and the small island states of Micronesia (Ministry of Pacific Island Affairs n.d.). There are important cultural and historical differences between these groups, as well as differences in citizenship and residency rights that reflect New Zealand's history as an administrative and colonial power in the Pacific, all of which make it tough for Pacific media, which face the challenge of navigating many cultural forms and languages. As Macpherson, Spoonley and Anae (2001) attest, Pacific cultural identity does not rest on a homogenous set of shared social experiences. Rather, Pacific identities reflect the varied historical, social, material and legal conditions in which they have been constructed and reconstructed (Macpherson 1999), and differ depending on which 'island' group one belongs to, whether one is overseas- or New Zealand-born, and even the degree of intermarriage across ethnic groups.

In particular, there is an emerging fracture between typically older Pacific migrants and younger New Zealand-born Pacific peoples, which marks significant intergenerational and cultural transformation within Pacific groups (Ministry of Pacific Island Affairs 2006). The social and material experiences of New Zealand-born or -raised Pacific peoples are diverging in terms of the ways they perceive themselves and the importance placed on their Pacific identity (Tiatia 2008, 6). This is particularly so among those New Zealand-born with 
mixed ethnicity, who are increasingly adopting a shared Pacific 'Nesian' or 'fa'a NiuSila' identity that departs significantly from their parents' and grandparents' migrant origins and traditions (Macpherson 2001; Teaiwa and Mallon 2005, pp. 210-211). As such, New Zealand is in a moment of transition regarding both its Pacific population, which is undergoing significant intergenerational and cultural transformation, and its media, which, like media elsewhere, are grappling with the need to reinvent themselves in a digital age.

\section{Pacific media}

New Zealand's Pacific media are mostly small, under-resourced and heavily reliant on state funding and patronage from other funding sources, and there is high degree of churn within the field. They are highly diverse in terms of media type, language and audience (multi-ethnic or specific ethnic, national or local). Several are cross-platform, and many blur the lines between traditional corporate and community categories, which makes it hard to generalise about the Pacific media landscape or to categorise according to established theories of community media, minority language media, alternative media and so on.

Within the broader New Zealand mediascape, which is dominated by outlets that are largely Pākehā-dominated and, in the commercial sector, foreign-owned, Pacific media are bit players. Outlets include a range of mostly small, family- or church-run newspapers; two national magazines (Spasifik and Suga); a handful of radio stations (for example, the Samoan language station Radio Samoa); a handful of community television programmes (such as $T$ News); and a growing number of online media such as Moana TV, Kaniva Tonga and TheCoconet.tv (Utanga 2007; Kailahi 2009). They operate on different scales, with churchrun newspapers sitting alongside medium-sized corporates such as Spasifik magazine and larger public broadcasters such as Niu FM, and they rely on a varied workforce that includes 
trained journalists and untrained employees and volunteers. They also operate under varying degrees of regulatory and bureaucratic restraint, but all (even those that enjoy state funds) face the challenge of having to meet the needs of diverse Pacific audiences that cannot be easily addressed with universalising content and that are also undergoing significant demographic change.

\section{Literature}

The few works on Pacific media in New Zealand (Utanga 2007; Kailahi 2009; Robie 2009; Papoutsaki and Strickland 2008; Neilson 2015) helpfully highlight their role in combating negative stereotypes, as well as the challenges they face regarding a lack of resources and competition for small but highly diverse audiences. However, they have little to say about how they are responding to these challenges, and most of these works are now out of date. The wider literature on ethnic minority media is small and dispersed across different disciplines, and much of it has been investigated through case studies which, while informative in specific situations (Le, 2015), do not necessarily translate in the New Zealand context.

A dominant line of research on ethnic media has concentrated on media content, particularly the use of racialised stereotypes and systematic under- and misrepresentation of minority ethnic groups (for general summaries see Cottle 2000; Downing and Husband 2005; Gandy 1998; and Wilson, Gutierrez and Chao 2003). There is also a strand of research summarising the extent to which ethnic media are constrained by structural and commercial realities such as poor resourcing (e.g. Riggins 1992); a lack of trained staff (e.g. Ojo 2006); limited audiences and therefore advertising reach (Sinclair 2009); and patronage and dependency on majority authorities (Caspi et al. 2002, p.552). 
Various works have described the role of ethnic minority media as maintaining the language and culture of an ethnic group, combating negative stereotypes, and providing a counter-narrative to mainstream media reporting, self-representation, news about an ethnic community and a public sphere (see Browne 2005; Forde et al. 2009; Georgiou 2004; Hanusch 2013; Karim 2008; Matsaganis, Katz and Ball-Rokeach 2011; and Riggins 1992). Bailey (2015) says media are key resources for shaping ethnic communities' identities, while Lay and Thomas (2012) argue that media have symbolic value for community, identity and social cohesion. Various studies have examined the role of media in identity formation (see, for example, Gillespie 1995 and Tsagarousianou 2001a, 2001b). However, as Nurse, Gibson and Suranyi (2015) note, the extent to which media interact with minority identity formation remains highly ambiguous.

Adriaens (2012) argues that studies exploring ethnic media's role in identity formation have tended to disavow the heterogeneity and diversity of audience identities and media offerings, and it is clear from some studies that producers' diverse identity positions (and contexts) have a material bearing on what representations are created in the media. Naficy (1993) and Milikowski (2001) have noted that diasporic migrant media portray their ethnic 'homelands' and culture differently from 'homeland' media. Shi (2009), Tsagarousianou (2001a, 2001b), De Santis (2003) and Davila (2001) argue that transnational media produced in the 'homeland' or other diasporic locations often fail to address the needs and interests of diasporic communities who want local content that is specific to their host country and their local communities. They treat them, instead, as part of a homogenised, transglobal ethnic group, serving up content that is designed for a different geographical and often social, historical, political and economic context. All of which begs questions about 
what it is that makes New Zealand's media 'Pacific'. Certainly, it suggests that empirical research needs to be sensitive to the way this category is a construct of producers (and policy makers and audiences) - and is not the same for the diverse members of each group.

As well as drawing on literature about ethnic minority media, this study also refers, in an indirect way, to Bourdieu's field theory, which sees the world as a series of inter-related social spaces that are structured by competing forces and within which practical actions become regulated over time and social actors compete to accumulate different forms of capital (Bourdieu 1998, 1998a). The concept is useful as one of several lenses for understanding Pacific producers' talk, though has not been used here to shape the research design or analysis. Instead, the discussion that follows draws indirectly on the theory's insights to understand the practice of journalism as both influenced by structure and agency, and configured by complex divisions (Neveu 2007, p.337), such as that drawn between Pacific-leaning and journalism-leaning media. In sum, Bourdieu's theories about fields and forms of economic, cultural and social capital provide a tool for understanding the spaces in which the performances of Pacific identity gain some of their meaning.

\section{Materials and methods}

This paper reports on part of a wider study of Pacific media and audiences in New Zealand (Ross 2017). It is based on in-depth, semi-structured interviews with 23 Pacific news media producers, which aimed to explore how the creators of Pacific media content understood their role and the purpose of Pacific media. Interviews were undertaken with producers from news media that best represented diverse mediums, ownership, organisational 
structure, target audiences and language (including English, bilingual and Pacific languageonly). All interviews were one-on-one except for one interview with three Samoa Nius journalists who were interviewed together at the newspaper's offices. Most interviews lasted between an hour and an hour and a half, and used a loose guide to give each interview a shared focus of inquiry. Interviews were kept deliberately open-ended, and questions broadly probed how producers defined Pacific media, what they thought made their outlet Pacific, what they did that was different from media that did not have a Pacific identity, who they saw as their target audience and how they interacted with them. All interviews were recorded and transcribed in full, amounting to more than 240,000 words of data. A handful of producers provided more comment after reviewing their transcript, and five were followed up to clarify their interview responses.

As a former journalist and a third-generation member of New Zealand's Pacific community, I was positioned as an insider with the media producers interviewed for this study. On the other hand, as someone who can claim only 'part' Pacific ethnicity (and who does not speak a Pacific language), I was an outsider and that location between insider and outsider positions required extra care. As such, I established a Pacific Advisory Group, comprising community and media representatives, to oversee and provide advice on the research project, including advice on research design and 'best practice' for working with Pacific communities.

\section{Results/Discussion}

In their interviews, Pacific producers drew on different resources to construct their identities and those of their media. On the one hand, they drew on cultural norms to emphasise the 'Pacific' legitimacy and distinctiveness of their work and, on the other, norms 
of professionalism and objectivity to emphasise their journalistic legitimacy. Significantly, when they compared themselves with each other, that is within the Pacific media landscape, this distinction was brought into sharp relief. What emerged was a tension between the different fields in which Pacific media are located - a field of Pacific norms and practices (which is shaped more by Pacific norms of 'authenticity') and a field of journalism norms and practices that demand different things of media producers (which appears to support the argument advanced elsewhere [Husband 2005; Matsaganis and Katz 2014], that ethnic media professionals' identities are influenced by complex, cross-cutting interactions with mainstream media and social institutions, and the ethnic communities they serve). This tension provides a lens for understanding the complex forces shaping identity practices within Pacific media production - and for stepping back from rigid categories to better account for the complexity of Pacific media.

For instance, producers of English-language Pacific media defined themselves in relation to dominant mainstream media via a discourse of Pacific 'perspective', which revealed a tricky and at times strategic negotiation of Pacific identity. It relied on a notion about innate Pacific worldviews, described variously as a 'Pacific style of telling stories', a 'Pacific focus', a 'Pacific voice', a ‘true' voice, 'Pacific flavour', 'Pacific understanding', 'Pacific approach', 'Pacific spirit', a 'Pacific perspective', a 'sense of Pacificness', an innate 'knowing' and a 'Pacific viewpoint'. Pacific peoples look at things differently; as one producer said: 'it's pretty much innate to think of community, to think of family from those perspectives; to think of environment and all those factors; to think in a spiritual way as well'. It is that perspective that makes Pacific media unique, he said; without it, 'you become like mainstream, there's no point of difference'. The concept is essentialising but nebulous, even for producers. When pressed to explain what a 'Pacific perspective' entailed, producers 
turned to anecdote. One described being asked to write reports for Samoan media when he was working in mainstream media.

I said, 'Oh yeah, I'd be happy to' and then I mentioned that I was Samoan through my mum, because obviously, my name is Scottish through my dad. He said, 'I knew it! I knew it in your stories, the way you write about our people. That's why I asked you. _Pacific media producer

Another described the difference between working with a Pākehā and a Pacific camera operator, saying the Pacific operator got 'so much closer to the heart of the story' because he: has so much more sensibility and understanding that the camera even moves in a different way $[\ldots]$ even small examples of understanding, that if there is a gesture in the room he knows where the reply is going to come, he knows that there's going to be a reply from a certain place in the room, so the camera will move automatically to catch that gesture, whereas [with a non-Pacific camera operator] the camera doesn't move or by the time it's moved it's gone, they've missed the moment. Pacific media producer

Notably, where all of the English-language media producers asserted the concept of a 'Pacific perspective' in some form or another, only one Pacific language-oriented media producer $^{\mathrm{i}}$ resorted to the same discourse - all others called on language to differentiate their media product. And the use of the 'Pacific perspective' discourse by the one Pacific language-oriented producer revealed important boundary-marking work. That producer, who was involved in the longstanding Tongan language news programme TNews and the newer pan-Pacific, English-language programme Pacific Viewpoint, resorted to the 'Pacific perspective' discourse not to talk about TNews but to contrast the English-language Pacific 
Viewpoint with Television New Zealand's English-language Pacific programme, Tagata Pasifika.

We produce our programmes from the perspective of the Pacific people. I always try and put our shows in the eyes of the Pacific people. I think if somebody asks me, 'What is the difference between Pacific Viewpoint and Tagata Pasifika?', I think that Tagata Pasifika is a Pacific programme, but it is produced from a Palagi ${ }^{\mathrm{ii}}$ perspective, maybe, and the ideology of TVOne as a whole is coming through the programming of Tagata Pasifika, even though it is run by Pacific people ... That's why we call it Pacific Viewpoint - it's so different from the Palagi viewpoints. _Pacific media producer

It was at boundary moments such as this that the 'Pacific perspective' discourse took on meaning - when producers made sense of their media's 'Pacificness' in relation to others. What's more, in interviews with Pacific producers, it appeared to have meaning mainly in an English-language context, that is, when producers could not call on more clearly defined markers such as language. News media that were in English and pan-Pacific (that is, served more than one Pacific ethnic group) had fewer Pacific cultural and symbolic resources to draw on, so drew on what is, in effect, an essentialising Pacific discourse to define their uniqueness or 'Pacificness'.

Interestingly, producers resorted to this discourse despite railing against essentialist identities at other times. A producer who resorted more often than most to the discourse of 'Pacific perspective', was also the most outspoken in challenging orthodox Pacific identities based on language and 'homeland' orientation. Others have noted elsewhere (Madianou $2005,2011)$ the paradoxical juxtaposition of a dominant discourse that reifies culture and identity and a demotic discourse that challenges and works against such reifications. They 
have suggested that people adopt the essentialist discourse when they are confronted with 'closure' by dominant agents (Madianou 2005, 2011), that is, when they are confronted with representations that categorise them as the 'other'. In the case above, resort to the Pacific perspective discourse was possibly a reflection of that media product's positioning as a panPacific English-language product in a dominant mainstream media space. Pacific media producers that reside in that space must spell out their distinctiveness from mainstream media to establish their brand and market share (and, if state-funded, to justify their special character funding). However, cultural identity is much harder to define and differentiate for media targeted at a conglomerate identity rather than an ethnic-specific community such as Tongan or Samoan.

Notably, the representations at their disposal were circumscribed by the structural and ideological context (described elsewhere as a racial political economy [Abel 2011]) within which Pacific media reside. Matsaganis and Katz (2014) found ethnic media professionals' identities were influenced by their interactions with mainstream media and social institutions - and the people who hold positions of power within them. In this study, the broadcast media producers who were most dependent on state resources described being constrained by dominant institutional culture or conservatism; corporate gatekeepers; state regulatory frameworks and policy (such as the requirements on Niu FM to promote Pacific languages); and the attitudes and cultural capital of Pākehā programme commissioners, editors, and colleagues.

They filter Pacific voices by not placing importance on a particular issue or perhaps by allowing or seeking a controversial slant where there needn't have been, or by putting their own take on an issue without it being accurate, culturally accurate. Pacific journalist 
It gets a little harder and harder as we go further along as far as how much control we have of our voice because at the end of the day it gets filtered through broadcasters. _Pacific media producer

$[\mathrm{X}]$ has done a lot to help change perceptions about Pacific people $[\ldots]$ But it is a lonely battle and it's always sporadic; there's one here, two there. You know, the browning of the media; it is happening, but we don't need it just in the front, people presenting, we need it with producers and the ones that make the hardcore decisions [...] we don't have enough Pacific mainstream chief reporters and editors._Pacific journalist

Tagata Pasifika really serves the machine and the machine says, 'You will do this and you will be here' and a lot of that has got to do with - there's a lot of politics involved, there used to be the charteriii - there's so much involved, politics, politicians, everything like that, and that's what Tagata Pasifika is. It is a vehicle for a lot of things other than its audience._Pacific media producer

These Pacific media, then, negotiate identity more often within a context of Pākehā understandings of 'Pacificness', which can pressure producers to emphasise more specialist identities over inclusive ones (Matsaganis and Katz 2014, p.932).

It was also apparent in the talk of producers of English-language Pacific media that their identity was also shaped by mainstream norms of journalistic practice. Indeed, they drew on journalistic norms to critique those whom they said put language and culture ahead of professional values and practice - 'some people think that language and credibility in the 
community automatically makes them a journalist'. Doing the news, according to these norms, is about more than telling stories; among other things, it is about being the Fourth Estate watchdog and holding power to account. One producer said his media outlet constantly worked to build its relationship with the community, especially the church, but was clear that it was there to do journalism, including hard stories. 'We're clear that we're a newspaper and we can't be on your side [...] We try to let them know what we do and that if you do something wrong it will be in the paper'. In addition, Pacific journalists drew on professional norms of practice, accuracy and style to contrast themselves with those in other Pacific media.

Given the amount of time people have had to sort things out in Pacific media, I am strongly of the view these days that it needs to come under a mainstream framework, rather than a standalone, because the resources are lacking, the skills are lacking, and there's no way I would encourage anyone to go into a Pacific newsroom._Pacific journalist

I'm very professional. I'm a stickler on punctuality and that wasn't happening in those Pacific networks [...] Don't stay in your comfort zone, don’t just stay working in Pacific media. Get out of your bad habits and go somewhere where it's structured, which is mainstream._Pacific journalist

A New Zealand Pacific producer described his newspaper as neatly designed, 'very professional', and up with other mainstream community newspapers in Auckland in terms of its 'uncluttered' style.

We want to be seen as going forward and really competing with the best [...] and not just be stuck in the old-style Pacific. If you see the other Samoan papers, then there's 
about 50 colours in the front page and a lot of writing and stuff._Pacific media producer

Another producer contrasted his journalism background with Pacific media, which he viewed as being of a different standard.

Because I come from the mainstream environment it's really a matter of taking bits out of that, which I thought weren't represented among Pacific media. I don't mean that in a condescending way, but just in terms of the standard. I remember a friend of mine had a photo framed that was run in one of the Samoan papers. She loves it because every name in the caption was spelt wrong._Pacific media producer In these ways, these English-language-media producers drew distinctions based on journalistic status.

In fact, English-language Pacific media producers were the most likely to orient to professional journalism norms and status, and that may reflect the fact they compete with majority media, and their connections to the dominant sphere are therefore relatively closer. The concept of social capital is useful here, as producers can be seen to be competing for not only audiences but also even more for cultural authority and social capital with mainstream media and institutions. Some Pacific media productions, like Tagata Pasifika, operate inside mainstream media organisations or, like Niu FM, are regulated via their funding and governing structures by dominant mainstream media practices. Spasifik competes with other mainstream higher-cost magazines and its editor said it was not enough to be seen as a good Pacific publication: 'I want it to be seen as good as mainstream, where someone who buys the Listener or reads North and South will read Spasifik, get some sort of value out of it'. New Zealand Pacific competes with other mainstream community giveaways; Niu FM competes directly with mainstream commercial radio stations Mai FM and Flava; and Pacific 
Beat Street's producers competed for programming opportunities on mainstream television. Thus, English-language media were positioned differently to Pacific-language media by having to attend more to the commercial, regulatory, professional and cultural dynamics that inform and shape mainstream media practice, and they were, therefore, oriented much more to a New Zealand journalism field and its professional identities.

It is possible, too, that their professional status claims also reflect a burden of representation felt within that field, where Māori and Pacific media have often been reported within a frame of 'brown failure'. Māori Television's attempts to get on air were repeatedly negatively reported (Paul 2005), while Niu FM and Radio 531pi's internal wrangling (which involved mediation and public allegations of contract breaches and profligate spending) was staged in public and widely reported (Misa 2003). This external criticism and framing put higher-profile English-language Pacific media and state-funded Pacific media under additional pressure to prove their professionalism and corporate responsibility.

While producers of English-language, pan-Pacific media leant toward discourses framed by journalistic norms, the converse was true in Pacific-language-oriented media producers' talk. They framed their comparisons of Pacific media not in terms of journalism, but in terms of Pacific authenticity. In some respects, this is unremarkable. Skjerdal (2011, p.728) notes that many ethnic media managers are not professional journalists in the common (Western) sense of the term. That discourse is unlikely to be a central part of their framework as many had not been educated as journalists, were rarely members of a professional media organisation, and, for many, their main occupation was often something other than the media venture. However, while that may rule out the use of journalistic norms in framing their identities, it does not explain the norms that were ruled in. Pacific-language-oriented media 
producers' talk was so grounded in Pacific norms and a Pacific field that producers appeared to have little need to distinguish themselves from mainstream media. Instead, their boundarymarking was with other Pacific media, indicating that their sense of identity was framed within a Pacific space - a space that is patterned by power relations and hierarchies based on forms of capital, such as language, age, cultural knowledge, gender, genealogy, family and service (Mila-Schaaf 2010). Within that field, the ability to perform cultural capital such as speaking a Pacific language affords prestige and profit (Mila-Schaaf 2010, p.248), and these producers' focus on Pacific heritage languages, for instance, might be understood partly in terms of competition for capital and power.

In their talk, Pacific-language-oriented media producers tended to 'other' Englishlanguage Pacific media and journalists as 'mainstream' and, implicitly, not Pacific enough. For instance, one described New Zealand's Pacific Islands Media Association (PIMA) as 'fake':

They are not Pacific media, because they are mainstream media, but they are Pacific people $[\ldots]$ For us, that is working in the Pacific media and started from Pacific media is the perspective of - when you come from mainstream, I guess, and I have nothing against the mainstream because I love what they do and it's great - but I think you are coming with them behind you, and it's them that you'll represent in the PIMA._Pacific media producer

This producer was, like many Pacific producers, not trained in journalism and distinguished themselves from PIMA and those 'glamorous Pasifika media' who were professionally trained. Another producer criticised Niu FM for not showing enough respect toward interviewees (in Pacific terms, deference toward one's elders and leaders is an orthodox 
Pacific value), by describing Niu FM as imitating the Palagi mainstream, which they said inappropriately grilled interviewees, especially politicians.

We work on the thing that if I respect you, you respect me. If I don't respect you I don't expect you to respect me, and that's how we work here. And I must say that it's not the same with other Pacific radio in Auckland. They have a different - some of them they actually trying to imitate the Palagi mainstream and it's sad when I see that because I think no, no, you should be unique, you should be Pacific - don't try and imitate something, which you are not [...] I think they actually should uphold all the things which is unique for Pacific, you know, their values, the language, the formal language they must adhere to - not the slang and the language that you don't actually expect from educated or well-trained brought up sort of Samoans._Pacific media producer

In these ways, Pacific-language-oriented producers positioned themselves not in mainstream media or journalistic terms, but in terms of Pacific cultural authority.

No doubt, arguments about what constitutes proper 'Pacificness' take place in every Pacific newsroom, but its manifestation in Pacific-language-oriented media producers' talk about other Pacific media, rather than in English-language media producers' accounts of the language media, is interesting, and may reflect a stronger degree of community embeddedness. Reader and Hatcher (2012, p.16) argue that community journalists typically place less value on the norms of the profession at large than on the norms of the individual communities they serve. Smaller Pacific language media, which in New Zealand tend to be localised community media, are arguably more intimately connected to their communities than larger English-speaking, pan-Pacific media such as Tagata Pasifika, which are nationally focused and further removed from localised and/or tight-knit ethnic-specific 
communities. Again, the producer above who described PIMA as 'fake', distinguished themselves from PIMA and (trained) Pacific journalists by describing themselves as more connected to community: the 'down to earth' media that 'really know the reality of people'.

Indeed, these media often have close relationships to other pillars of the Pacific community, such as the church (Nafiz 2012). As a result, these media are likely to be more conscious of Pacific community norms on a day-to-day basis and, possibly, more heavily policed. Matsaganis and Katz (2014, p.937) argue that ethnic media producers are affected by pressures from the mainstream (as appears to be the case for English-language Pacific media above) and from the ethnic communities they serve. That is especially so when they cover specific and clearly defined, smaller populations, as do Pacific-language media, where there is more limited access to human and financial resources (staff, advertising revenue and so on) and, usually, greater interdependence between the media and their communities at the institutional level (ibid.). Their closer proximity to Pacific institutions of power, such as the church, may intensify the strain of professional norms that require watchdog journalism - and the better fit of Pacific norms.

In the same way, the 'Pacific perspective' discourse deployed by English-language producers possibly helps to mark their belonging to the Pacific field in a way that least contradicts their journalistic affiliations and which is difficult for Pacific-language competitors to challenge. It may be a complex cultural response to in-group 'othering' by Pacific-language-oriented media producers who, speaking from a Pacific space and orthodox Pacific discourse, 'misrecognise' English-language producers and their media (Mila-Schaaf 2010; Southwick 2001) by describing them as mainstream, non-Pacific, and even 'fake'. The 'Pacific perspective' discourse allows producers who are identified in this way to push back 
by calling on immutable qualities of innate Pacificness that claim their Pacific identity and belonging in a way that is strategically hard to pin down and difficult to dispute. It is an example of how the boundaries are not always fixed. In a way that mimics how humour works, meaning-making in this regard requires familiarity with the competing discourse(s) and messages that are encoded to enable speaking to multiple audiences without giving overt offence to any. As such, this discourse may respond more usefully, too, to the more complex realities of inter-generational Pacific audiences, unlike the Pacific field's more essentialising discourses about Pacificness, which are not as useful for media producers communicating with the contemporary young, Pacific New Zealand audience.

The tension seen here between journalism-leaning and Pacific-leaning discourses and practice within the Pacific mediasphere extends Husband (2005) and Matsaganis and Katz's work (2014) on ethnic media producers' communities of practice. It does this by demonstrating two different communities of practice within the Pacific media sphere that diverge around journalistic and Pacific norms, depending on the influences of their wider social, political and economic environments. It is possible that the tension between the two, particularly with regard to discourses about proper Pacific media content, indicates the lack of a professional Pacific journalism institution for producers to call on to determine standards. PIMA is small and under-resourced (and covers all media, including film and entertainment, not just news media). At its AGM in 2013, it barely managed a quorum and its executive noted that the lack of attendance and apparent lack of interest from Pacific media could signal that it had had its day (Pacific Media Watch 2013). Thus, without a professional institution that might develop a Pacific journalism, producers fall back on either Pacific community or mainstream journalistic norms, and are pulled in different directions without any clear or stable place to stand. 


\section{Conclusion}

Far from being a homogenous entity, Pacific media are diverse and often in contest with each other. As this paper demonstrates, they are not necessarily in-language but are differentiated by different discourses and practices of language and 'Pacificness', which make it hard to categorise them according to the definitions of language and diaspora often asserted in the ethnic media literature. By looking more closely at how producers position themselves in different contexts, it becomes apparent that there are several tensions running through New Zealand's Pacific news media, including a tension between two fields of journalistic and Pacific norms that appear to depend on media outlets' positioning in relation to language, mainstream institutions and their ethnic community. This divide is not rigid (a producer who saw themselves as not belonging to PIMA, joined its executive; another who insisted Samoan language was the sole concern for Pacific media engaged journalism tutors to run in-house news training for staff), but it does demand a rethink of how we conceive ethnic media. As a first step in answering how we should understand Pacific media theoretically, this paper argues that we must start with theories that can foreground diversity, complexity and dispute.

It also proposes that these various practices of 'Pacificness' might be seen as locative practices, that is, strategic ploys to locate oneself and one's media in relation to community (a positioning of connection and belonging) and in relation to other Pacific and mainstream media (a positioning that draws on dissimilarity and 'otherness'). This is about identity, but it is also more than that. In describing these practices as locative, I draw on the socio-spatial concepts of tūrangawaewae ${ }^{\text {iv }}$ (a place of strength and belonging, a place to stand) and va (sacred space/relationship), which are more powerful and expansive concepts for 
understanding identity in terms of what Brown Pulu (2002) describes as 'belonging-ness', that is, community, relationships and connection. Literally, tūranga (standing place) and waewae (feet), the Māori term tūrangawaewae refers to places where we feel especially empowered and connected, and which are 'our foundation, our place in the world, our home' (Royal 2007). It can refer to place but it also has meaning socially and can refer to relationships and important ancestors (ibid.). Broadly, the concept speaks to the connections that give us our sense of security and foundation, and that locate us in the wider world. It is, I suggest, a helpful lens for viewing the practices described here as more than just practices of identity, but as multi-faceted practices of identity and relationships and the right to represent. Similarly, the Samoan/Tongan concept of va, which invokes the notion that we are part of a complex web of interdependent and reciprocal relationships (Mila-Schaaf 2010), helps us to understand identity positions as temporal and relational and locative practices as grounded in specific contexts and specific relationships.

In Tongan communities, relationships or the space between any two individuals, groups or between communities and nature are defined by the context in which the interaction occurs. Thus, when the context changes, the relationship changes also (Taufe'ulungaki 2004 cited in Mila-Schaaf 2010, p.107).

In these ways, the concepts of tūrangawaewae and va help to underpin an attempt to explain and theorise Pacific media producers' practices as locative, rather than just identity-driven. They help to keep the social and relational aspects of identity to the fore, and to understand these practices in multi-dimensional terms as both structured and structuring.

According to Husband (2005, p463), and evidenced above, the identities generated by minority ethnic media are shaped by forces that are specific to the demographic formation of their communities and their socio-political location within wider society, and are artefacts of 
the power relations between majority and minority interests. As such, this paper's analysis of Pacific media producers' locative practices helps to reveal some of the power relations embedded in Pacific media outlets' structural, cultural and ideological contexts. Unlike members of the dominant group, who have arguably more stability in identity, Pacific peoples' identity is always negotiated, and in ways that must continually answer back to the different forces that position them. In this way, Pacific media can risk producing a refracted language of dominant groups, whether that of Pacific elites, state institutions or mainstream media and their professional norms.

Thus, Pacific language-media producers, who were more distanced from majority media and dominant 'White' spaces, and might even be described as positioned within Pacific ethnic enclaves, were more likely to construct identities that were rooted in dominant Pacific discourses. They used language as their primary locative practice presumably because a) language is an important cultural marker (see Cormack and Hourigan 2007); b) they could (they were all Pacific language speakers); and c) language lends significant status in the orthodox value systems of their Pacific space. But that means they speak to an orthodox identity that is shaped by migrant experiences and privileges Pacific elites (when most Pacific peoples are now New Zealand-born and -raised and cannot speak a Pacific language), which begs whether these media have an expiry date. Matsaganis et al. (2011) cite numerous examples of declining ethnic media audience numbers in the face of changing demographics, including the decline in ethnic language competency among second and subsequent generations. In many cases where ethnic media have failed to reflect the intergenerational changes of the communities they serve, by continuing to produce content in a language no longer spoken by most of the community, they have gone bankrupt (Matsaganis et al. 2011, p.87). 
Producers of English-language Pacific media were positioned differently, and appeared to straddle Pacific and journalistic spaces. Significantly, they employed locative practices from each space to distinguish themselves: they were this, but not that at a boundary with Pacific language media (where they located themselves via a journalistic discourse of professional media practice) and that, but not this at the boundary with mainstream media (where they located themselves via a 'Pacific perspective' discourse). In doing so, they appeared to be carving out territory that is neither wholly 'Pacific' nor mainstream, but a Pacific place to stand within a wider media landscape. 


\section{References}

Abel, S., 2011. The (racial) political economy of Māori Television. Australian Journal of Communication, 38 (3), 125-138.

Adriaens, F., 2012. On mute, diaspora youth. A transdisciplinary and multi-method audience study into using, consuming and doing television among diaspora youngsters. Unpublished PhD thesis. Universiteit Ghent.

Bailey, O., 2015. Diasporic media in multicultural societies. In C. Atton (ed.), The Routledge Companion to Alternative and Community Media. Abingdon, UK and New York: Routledge, pp.414-425.

Bourdieu, P., 1998. On Television. New York: New Press.

Bourdieu, P. 1998a. On Television and Journalism. London: Pluto Press.

Brown Pulu, T., 2002. Turangawae/Tu'ungava'e: Echoes of a place to stand and belong. He Puna Korero: Journal of Maori and Pacific Development, 3 (2), 14-30.

Browne, D., 2005. Ethnic Minorities, Electronic Media and the Public Sphere: A Comparative Approach. Cresskill, USA: Hampton Press.

Caspi, D., Adoni, H., Cohen, A.A. and Elias, N., 2002. The red, the white and the blue: The Russian media in Israel. International Communication Gazette, 64 (6), 537-556. 
Cormack, M. and Hourigan, N., 2007. Minority Language Media: Concepts, Critiques and Case Studies. Clevedon, Toronto: Multilingual Matters Ltd.

Cottle, S., 2000. Ethnic Minorities and the Media: Changing Cultural Boundaries.

Buckingham, UK: Open University Press.

Davila, A., 2001. Latinos, Inc.: The Marketing and Making of a People. Berkeley: University of California Press.

De Santis, H., 2003. Mi programa es su programa: Tele/visions of a Spanish-language diaspora in North America. In K. Karim, ed., The Media of Diaspora. London: Routledge, pp.63-75.

Downing, J. and Husband, C., 2005. Representing 'Race': Racisms, Ethnicities and Media. London: Sage Publications.

Forde, S., Foxwell, K. and Meadows, M., 2009. Developing Dialogues: Indigenous and Ethnic Community Broadcasting in Australia. Bristol, UK and and Chicago, USA: Intellect.

Gandy, O., 1998. Communication and Race: A Structural Perspective. London: Arnold.

Georgiou, M., 2004. Consuming ethnic media, constructing ethnic identities, shaping communities: A case study of Greek Cypriots in London. In R. Lind, ed., Race/Gender/Media. Considering Diversity across Audiences, Content, and Producers. Boston: Pearson Education, pp.52-60. 
Gillespie, M., 1995. Television, Ethnicity and Cultural Change. London: Routledge.

Hanusch, F., 2013. Charting a theoretical framework for examining Indigenous journalism culture. Media International Australia, 149, 82-91.

Husband, C., 2005. Minority ethnic media as communities of practice: Professionalism and identity politics in interaction. Journal of Ethnic and Migration Studies, 31 (3), 461-479.

Kailahi, S., 2009. Pacificness - Telling our own side of the story. Pacific Journalism Review, $15(1), 31-37$.

Karim, K., 2008. Migrant community media. In W. Donsbach. ed., The International Encyclopedia of Communication. Blackwell Publishing. Accessed 18 May, 2010 at:

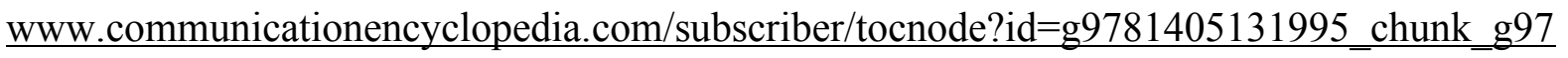
$\underline{8140513199518 \text { ss84-1 }}$

Lay, S. and Thomas, L., 2012. Ethnic minority media in London: Transition and transformation. Media, Culture and Society, 34 (3), 369-380.

Le, E., 2015. Media in minority contexts: Towards a research framework. Journal of Applied Journalism and Media Studies, 4 (1), 3-24.

Lewis, S.C., 2008. News, nationalism, and the imagined community. Journalism Studies, 9 (3), 409-428. 
Macpherson, C., 1999. Would the real Samoans please stand up? New Zealand Geographer, $55(2), 50-59$.

Macpherson, C., 2001. One trunk sends out many branches: Pacific cultures and cultural identities. In C. Macpherson, P. Spoonley and M. Anae, eds., Tangata o te Moana Nui: The Evolving Identities of Pacific Peoples in Aotearoa/New Zealand.. Palmerston North: Dunmore Press, pp.66-80.

Macpherson, C., Spoonley, P. and Anae, M., eds., 2001. Tangata o te Moana Nui: The Evolving Identities of Pacific Peoples in Aotearoa/New Zealand. Palmerston North: Dunmore Press.

Madianou, M., 2005. Contested communicative spaces: Rethinking identities, boundaries and the role of the media among Turkish speakers in Greece. Journal of Ethnic and Migration Studies, 31 (3), 521-541.

Madianou, M., 2011. Beyond the Presumption of Identity? Ethnicities, cultures, and transnational audiences. In V. Nightingale, ed., The Handbook of Media Audiences. Chichester; Malden, MA: Wiley-Blackwell, pp. 444-458.

Matsaganis, M., Katz, V. and Ball-Rokeach, S., 2011. Understanding Ethnic Media: Producers, Consumers, and Societies. Thousand Oaks, California: Sage. 
Matsaganis, M. and Katz, V., 2014. How ethnic media producers constitute their communities of practice: An ecological approach. Journalism, 15 (7), 926-944.

Mila-Schaaf, K., 2010. Polycultural capital and the Pacific second generation: Negotiating identities in diasporic spaces. Unpublished PhD, Massey University.

Milikowski, M., 2001. Learning about Turkishness by satellite: Private satisfactions and public benefits. In K. Ross, ed. with P. Playdon, Black Marks: Minority Ethnic Audiences and Media. Aldershot, UK: Ashgate Publishing, pp.125-138.

Ministry of Pacific Island Affairs., n.d.. About Pacific peoples in New Zealand. Accessed 4 January, 2016 at: http://www.mpp.govt.nz/pacific-peoples-in-new-zealand/

Ministry of Pacific Island Affairs, 2006. Pacific Analysis Framework: Analysing Public Policy through Pacific Lenses. Wellington: Ministry of Pacific Island Affairs.

Misa, T., 2003. The story behind the upheaval after Niu FM hit the airwaves. Pacific Journalism Review, 9, 170-176.

Naficy, H., 1993. The Making of Exile Cultures. Iranian Television in Los Angeles. Minneapolis: University of Minnesota Press.

Nafiz, A., 2012. Reaching the community through community radio: Readjusting to the new realities. Unpublished $\mathrm{PhD}$ thesis, University of Canterbury. 
Neilson, M., 2015. Pacific way: Auckland's Pasifika community diaspora media, Pacific journalism monographs no.5. Auckland, New Zealand: Pacific Media Centre.

Neveu, E., 2007. Pierre Bourdieu: Sociologist of media, or sociologist for media scholars? Journalism Studies, 8 (2), 335-347.

Nurse, L., Gibson, A. and Surányi, R., 2015. Media consumption and self-identification: Hungarian and Slovak case study. Identities, 23 (6), 705-724.

Ojo, T., 2006. Ethnic print media in the multicultural nation of Canada: A case study of the black newspaper in Montreal. Journalism, 7 (3), 343-361.

Pacific Media Watch, 2013. NZ: Bid to save PIMA from Pasifika media 'apathy', April 22. Accessed 1 December, 2016 at: http://www.pmc.aut.ac.nz/pacific-media-watch/nz-bid-savepima-pasifika-media-apathy-8267

Papoutsaki, E. and Strickland, N., 2008. Pacific Islands diaspora media: Conceptual and methodological considerations for a pilot study. Fijian Studies, 8(1/2), 166-184.

Paul, J., 2005. Challenges lie ahead for MTS in the Aotearoa public sphere. Pacific Journalism Review, 11(1), 42-48.

Reader, B. and Hatcher, J., 2012. Foundations of Community Journalism. Los Angeles: Sage. 
Riggins, S., 1992. Ethnic Minority Media: An International Perspective. Newbury Park, California: Sage Publications.

Robie, D., 2009. Diversity reportage in Aotearoa: Demographics and the rise of the ethnic media. Pacific Journalism Review, 15 (1), 67-91.

Ross, T. (2017) Locating Ourselves: An analysis and theoretical account of strategic practices of identity and connection in Aotearoa/New Zealand's Pacific news media. Unpublished $\mathrm{PhD}$ thesis. Christchurch: University of Canterbury.

Royal, T.A.C., 2007. Papatūānuku - the land - Tūrangawaewae - a place to stand. In Te Ara the Encyclopedia of New Zealand. Ministry of Culture and Heritage. Accessed 6 December, 2016 at: http://www.TeAra.govt.nz/en/papatuanuku-the-land/page-5

Shi, Y., 2009. Re-evaluating the 'alternative' role of ethnic media in the US: The case of Chinese-language press and working-class women readers. Media Culture Society, 31 (4), 597-616.

Sinclair, J., 2009. Minorities, media, marketing and marginalization. Global Media and Communication, 5 (2), 177-196.

Skjerdal, T., 2011. Journalists or activists? Self-identity in the Ethiopian diaspora online community. Journalism, 12 (6), 727-744. 
Southwick, M., 2001. Pacific women's stories of becoming a nurse in New Zealand: A radical hermeneutic reconstruction of marginality. Unpublished $\mathrm{PhD}$ thesis. Victoria University of Wellington.

Sreberny, A., 2005. Not only, but also: Mixedness and media. Journal of Ethnic and Migration Studies, 31 (3), 443-459.

Teaiwa, T. and Mallon, S., 2005. Ambivalent kinships? Pacific people in New Zealand. T. McIntosh, J. Liu, T. McCreanor and T. Teaiwa, eds., New Zealand identities: Departures and Destinations. Wellington: Victoria University Press, pp.207-229.

Tiatia J., 2008. Pacific Cultural Competencies: A Literature Review. Wellington: Ministry of Health.

Tsagarousianou, R., 2001a. A space where one feels at home: Media consumption practices among London's South Asian and Greek Cypriot communities. In R. King and N. Wood, eds., Media and Migration: Constructions of Mobility and Difference. London: Routledge, pp.158-172.

Tsagarousianou, R., 2001b. Diasporic audiences' media uses and constructions of 'community': The case of London's South Asian and Greek Cypriot communities. In K. Ross and P. Playdon, eds., Black Marks: Research Studies with Minority Ethnic Audiences. Aldershot: Ashgate, pp.17-32.

Utanga, J., 2007. Pasifika media in the digital era. Pacific Journalism Review, 13 (1), 19-28. 
Wilson, C., Gutierrez, F. and Chao, L., 2003. Racism, Sexism and the Media: The Rise of Class Communication in Multicultural America. $3^{\text {rd }}$ ed. Thousand Oaks: Sage Publications.

\footnotetext{
${ }^{i}$ Note, these categories are messy and are viewed here as orientations rather than fixed categories. The Niu FM producers interviewed for this study worked on English-language programmes and considered themselves as English-language media producers, though the station's night-time programming is in a variety of Pacific languages. Likewise, the TNews producer quoted here identified as a Pacific language producer and was oriented to a minority-language media space, despite also producing a companion programme in English (Pacific Viewpoint).

ii Pākehā/European.

iii The TVNZ charter, implemented in 2003, required the state broadcaster to show programmes that reflected New Zealand's culture and identity, while still maintaining its commercial profitability. By 2006, it was considered a failed experiment, and it was formally abolished in 2011 (Dunleavy, 2014). iv Tu'ungava'e in Tongan.
} 